Tropical Journal of Pharmaceutical Research April 2015; 14 (4): 599-604

ISSN: $1596-5996$ (print); 1596-9827 (electronic)

(C) Pharmacotherapy Group, Faculty of Pharmacy, University of Benin, Benin City, 300001 Nigeria.

All rights reserved.

Available online at http://www.tjpr.org

Original Research Article

http://dx.doi.org/10.4314/tjpr.v14i4.6

\title{
Improvement of 2-O-a-D-Glucopyranosyl-L-Ascorbic Acid Biosynthesis Using Ultrasonic Radiation
}

\author{
Ahmed I Eibaid ${ }^{1,2}$, Ming Miao ${ }^{1}$, Bo Jiang ${ }^{1 *}$, Mohanad O Bashari ${ }^{2}$ and Abubakar \\ Musa $^{1,3}$ \\ ${ }^{1}$ The State Key Laboratory of Food Science and Technology, Synergetic Innovation Center of Food Safety and Nutrition, \\ Jiangnan University, 1800 Lihu Road, Wuxi 214122, China, '2Department of Food Science and Technology, Faculty of \\ Engineering and Technology, ${ }^{3}$ Sugar Institute, University of Gezira, PO Box 20, Wad Madani, Sudan
}

*For correspondence: Email: bjiang@jiangnan.edu.cn; Tel: +86-510-85329055; Fax: 86-510-85919625

Received: 18 December 2014

Revised accepted: 16 March 2015

\begin{abstract}
Purpose: To improve 2-O- $\alpha-D$-glucopyranosyl-L-ascorbic acid (AA-2G) production using ultrasonic radiation (UR) treatment.

Methods: The production of $A A-2 G$ using UR or ultrasonic radiation with shaking (URS) at $150 \mathrm{rpm}$, at varying power $(100-500 \mathrm{~W})$, temperature $\left(30-65^{\circ} \mathrm{C}\right), \mathrm{pH} 4.0-9.0$, and time (2-24 h) was compared with that produced in a shaker water bath (SWB) in a reaction catalyzed by cyclodextrin glucanotransferase (CGTase) from Bacillus sp. SK13.002. The effect of URS on CGTase activity was also measured.

Results: Maximum AA-2G production using UR at a power of $400 \mathrm{~W}$, temperature of $37^{\circ} \mathrm{C}$, and $\mathrm{pH} 8.0$ for $18 \mathrm{~h}$ was $5.69 \pm 0.2 \mathrm{~g} / \mathrm{L}$, while URS at $500 \mathrm{~W} / 150 \mathrm{rpm}$ and $37^{\circ} \mathrm{C}$ for $14 \mathrm{~h}$ yielded $7.05 \pm 0.21 \mathrm{~g} / \mathrm{L}$ of AA-2G. URS at $500 \mathrm{~W} / 150 \mathrm{rpm}, 55^{\circ} \mathrm{C}$, and $\mathrm{pH} 8.0$ for $6 \mathrm{~h}$ yielded $6.6 \pm 0.25 \mathrm{~g} / \mathrm{L}$ of $\mathrm{AA}-2 \mathrm{G}$. URS at 37 and $55^{\circ} \mathrm{C}$ significantly increased CGTase activity. AA-2G yield using UR (400 W) was decreased by 9.7 $\%$ compared to that produced by SWB. However, the AA-2G yield using USS (500 W/150 rpm) at 37 and $55^{\circ} \mathrm{C}$ increased by 11.9 and $4.8 \%$, respectively, with a reduction in process time of 41.7 and $75 \%$, respectively, compared to that previously produced by SWB.

Conclusion: These results indicate that UR combined with shaking improves $A A-2 G$ production.
\end{abstract}

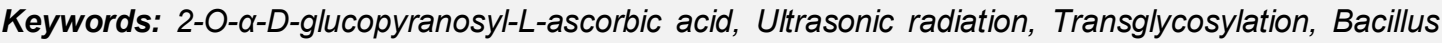
sp. SK13.002

Tropical Journal of Pharmaceutical Research is indexed by Science Citation Index (SciSearch), Scopus, International Pharmaceutical Abstract, Chemical Abstracts, Embase, Index Copernicus, EBSCO, African Index Medicus, JournalSeek, Journal Citation Reports/Science Edition, Directory of Open Access Journals (DOAJ), African Journal Online, Bioline International, Open-J-Gate and Pharmacy Abstracts

\section{INTRODUCTION}

The compound 2-O- $\alpha$-D-glucopyranosyl-Lascorbic acid (AA-2G) is a glycoside form of Lascorbic acid (AA). It is enzymatically synthesized via transglycosylation by mammalian a-glucosidase. Unlike AA, AA-2G is stable in the presence of enhanced oxidative degradation by heat, light, $\mathrm{Cu}^{2+}$ ion, or ascorbate oxidase, and it has no reducing activity toward radicals. AA-2G is available in vitro and in vivo as $A A$; therefore, it is used in cosmetics, medicine, and the food industry [1]. Increasing production of AA-2G using highly soluble and low cost glycosyl donors such as maltose and maltodextrin was recently reported [2,3], but the yield was still low compared to other substrates. Maximum production of $A A-2 G$ has also been reported, using different substrates and enzymes in reactions lasting 24-48 h [4]. 
Ultrasonic irradiation (UR) has been shown to increase the yield in various processes that involve both enzymatic and non-enzymatic reactions. However, UR decreased the times of the chemical reactions, while enzyme-catalyzed reactions were accelerated by UR [5]. Although enzymatic transglycosylation reactions have been accelerated by microwave radiation [6], to the best of our knowledge, there have been no published reports on the effects of UR on transglycosylation reaction using $A A$ for $A A-2 G$ production. Recently we used maltodextrin as a glycosyl donor for production of $A A-2 G$ via a transglycosylation reaction catalyzed by cyclodextrin glucanotransferase (CGTase, EC 2.4.1.19) from Bacillus sp. SK13.002 [7]. The aim of the present study was therefore to characterize the production of AA-2G under UR by using maltodextrin as a substrate.

\section{EXPERIMENTAL}

\section{Materials}

The AA-2G standard was obtained from Hayashibara Biochemical Laboratories (Okayama, Japan), while AA and glucoamylase were obtained from Sigma-Aldrich (Shanghai, China). Maltodextrin (DE 10-15) was purchased from the Grain Processing Corporation (Muscatine, IA, USA). All other analytical grade chemicals were purchased from Sinopharm Chemical Reagent Co Ltd. (Shanghai, China).

\section{Evaluation of hydrolytic activity of CGTase}

The hydrolytic activity of CGTase was measured by assaying the hydrolysis effect on starch, as previously described [6]. Briefly, based on the decrease of blue color intensity of the amyloseiodine complex formed after reacting CGTase with $0.3 \%(w / v)$ soluble starch in $200 \mathrm{mM}$ phosphate buffer $(\mathrm{pH} 8.0)$ at $65{ }^{\circ} \mathrm{C}$ and measured at $660 \mathrm{~nm}$. One unit of CGTase activity was defined as the amount of enzyme that catalyzed a $10 \%$ decrease of absorbance per min under the assay conditions.

\section{Determination of cyclization activity of CGTase}

The cyclization activity of CGTase was measured by the phenolphthalein method as previously described [8]. Briefly, a reaction mixture containing $1 \mathrm{~mL}$ of $0.04 \mathrm{~g}$ starch in $0.1 \mathrm{M}$ phosphate buffer ( $\mathrm{pH}$ 6.0) and $0.1 \mathrm{~mL}$ enzyme solution was used. The mixture was incubated at $60{ }^{\circ} \mathrm{C}$ for $10 \mathrm{~min}$ in a water bath. The reaction was stopped by adding $3.5 \mathrm{~mL}$ of $0.03 \mathrm{M} \mathrm{NaOH}$ solution, $0.5 \mathrm{~mL}$ of $0.02 \%(\mathrm{w} / \mathrm{v})$ phenolphthalein in $0.005 \mathrm{M} \mathrm{Na}_{2} \mathrm{CO}_{3}$ was added to the reaction mixture. After $15 \mathrm{~min}$, the decrease in color intensity was measured at $550 \mathrm{~nm}$. One unit of CGTase activity was defined as the amount of enzyme that forms $1 \mathrm{mmol} \beta$-cyclodextrin per min under the assay conditions.

\section{Partial purification of CGTase}

Bacillus sp. SK13.002 originally was isolated from a soil sample in our laboratory and screened by phenolphthalein - methyl orange method, it was found to produce CGTase [9]. The crude enzyme was obtained after fermentation for 4 days and centrifugation at $10,000 \mathrm{rpm}$ and $4{ }^{\circ} \mathrm{C}$ for 15 minutes. The crude preparation was concentrated, precipitated, dialyzed, and freeze-dried as previously described [6]. The resulting CGTase powder was used in all subsequent experiments.

\section{Ultrasonic equipment}

An experimental ultrasonic cleaner (model KQ500DE; Ultrasonic Equipment Co., Ltd., Kunshan, China) was used in this study. The internal dimension of the cleaning size $(\mathrm{mm})$ was $300 \times 300 \times 150$, with a capacity of $22.5 \mathrm{~L}$. The ultrasonic cleaner could deliver a maximum power of $500 \mathrm{~W}$ at $40 \mathrm{kHz}$ with adjustable time, power, and temperature. The temperature was kept constant by a continuous supply of cold tap water and drainage of hot water to prevent a rise in the temperature due to the UR. Ultrasonic radiation with shaking (URS) was constructed by using an arm fixed in a shaking water bath (SWB) (model HZ-8812S-B; Hualida Laboratory Equipment Company, Wenzhou, China) that extended inside the ultrasonic cleaner with a sample holding device.

\section{Biosynthesis of AA-2G}

The reaction was carried out using the following formula:

$A A+$ maltodextrin $(C G T a s e)=A A-2 G+A A-2 G n$ (Glucoamylase $)=A A-2 G+$ glucose

where $\mathrm{AA}-2 \mathrm{Gn}=\mathrm{AA}-2$-oligosaccharides $(\mathrm{n}$ is number of glucose units ranging from 2 to 6 ).

The reaction mixture consisted of maltodextrin $(0.016 \mathrm{~g} / \mathrm{mL}), A A(0.016 \mathrm{~g} / \mathrm{mL})$, and $400 \mathrm{U}$ of CGTase in $0.1 \mathrm{M}$ sodium phosphate buffer $(\mathrm{pH}$ 8 ), which was initially incubated at $37^{\circ} \mathrm{C}$ for $2 \mathrm{~h}$. Glucoamylase was added to the reaction mixture at $\mathrm{pH} 5.5$ and incubated at $65{ }^{\circ} \mathrm{C}$ for an additional $6 \mathrm{~h}$. 
Analysis of the reaction mixture for AA-2G production was carried out using an HPLC system consisting of an Agilent Technologies 1200 Series instrument (Alpharetta, GA, USA) as we previously described [7].

\section{Biosynthesis of AA2G using UR}

The AA-2G production was first carried out for 2 $\mathrm{h}$ using a sonication power of $200-500 \mathrm{~W}, \mathrm{pH}$ 4.0-9.0, temperature of $30-65{ }^{\circ} \mathrm{C}$, and a duration of $2-24 \mathrm{~h}$. The influence of URS on AA$2 \mathrm{G}$ production was studied for $2 \mathrm{~h}$ using a sonication power of $200-500 \mathrm{~W}, \mathrm{pH} 4.0-9.0$, temperature of $30-65{ }^{\circ} \mathrm{C}$, different substrate ratios and duration of $2-18 \mathrm{~h}$.

\section{Statistical analysis}

All experiments were performed in triplicate and the mean ( \pm standard deviation) recorded. Analysis of variance (ANOVA) was carried out and the results further evaluated by Duncan's
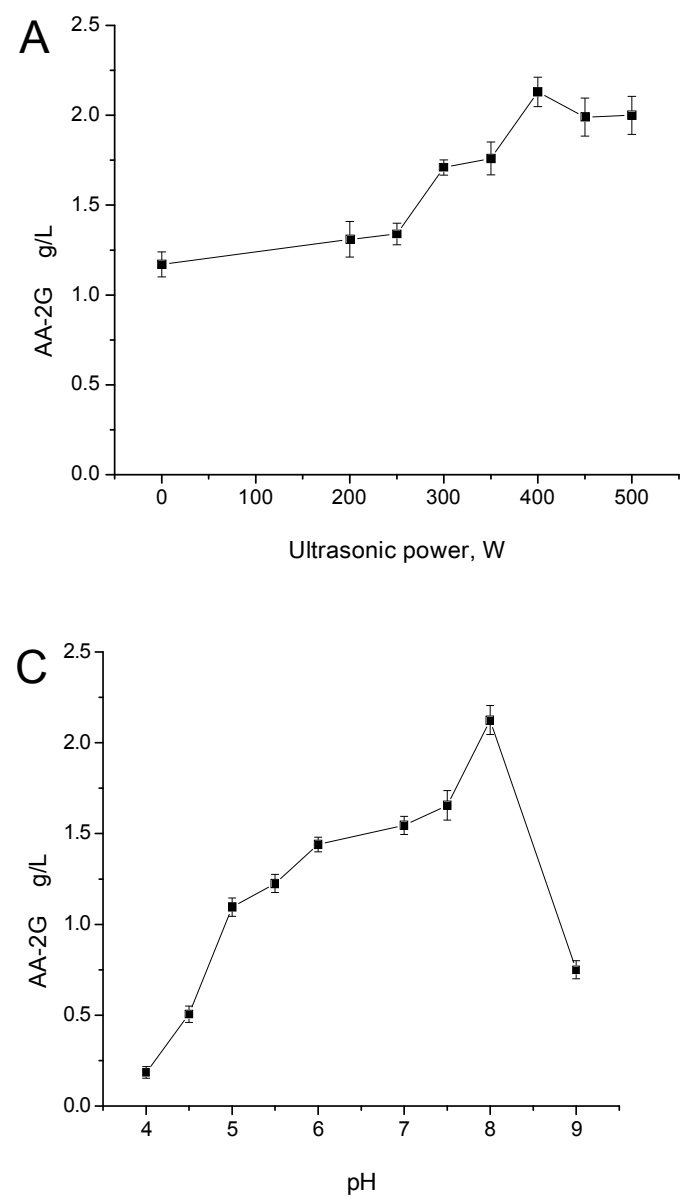

multiple range tests. Statistical software SPSS 17.0 (SPSS Inc, Chicago, IL, USA) was used for the analyses, and $p<0.05$ was considered statistically significant.

\section{RESULTS}

\section{Effect of UR on biosynthesis of AA-2G}

Biosynthesis of AA-2G using UR at $37{ }^{\circ} \mathrm{C}$ was compared with that obtained by conventional SWB as a control. Maximum production of AA$2 \mathrm{G}(2.13 \pm 0.08 \mathrm{~g} / \mathrm{L})$ in $2 \mathrm{~h}$ was obtained using an ultrasonic power of $400 \mathrm{~W}$ (Figure 1A). This yield represented a significant increase $(p<$ 0.05 ) of $82.05 \%$ compared with that produced by the control $(1.17 \pm 0.07 \mathrm{~g} / \mathrm{L})$. Reaction parameters such as temperature, $\mathrm{pH}$, and duration of time were optimized, resulting in maximum AA-2G yields $(5.69 \pm 0.2 \mathrm{~g} / \mathrm{L})$ at $37^{\circ} \mathrm{C}$ and $\mathrm{pH} 8.0$ after $18 \mathrm{~h}$ (Figure 1).
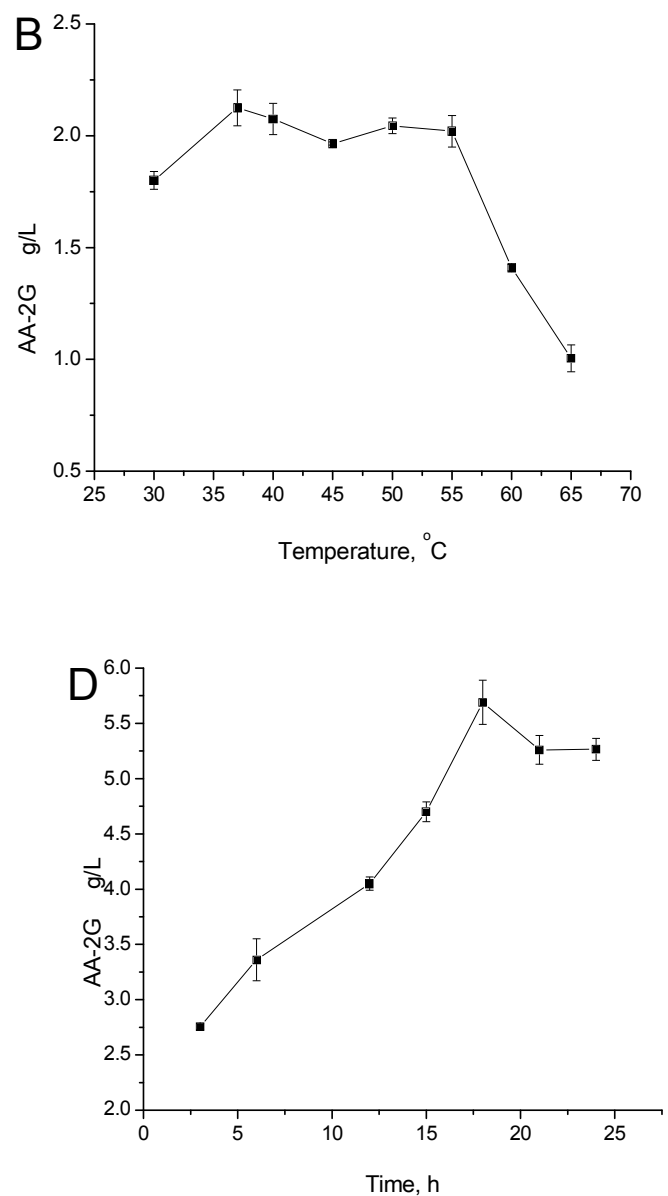

Figure 1: Effect of ultrasonic radiation (UR) on 2-O- $\alpha$-D-glucopyranosyl-L-ascorbic acid (AA-2G) production. (A) Effects of different power at $37^{\circ} \mathrm{C}$ for 2 hours, (B) the effects of different temperatures at $400 \mathrm{~W}$ for 2 hours, (C) the effects of different $\mathrm{pH}$ at $400 \mathrm{~W}$ and $37^{\circ} \mathrm{C}$ for 2 hours, and (D) the effects of different duration times at $\mathrm{pH} 8.0$, $400 \mathrm{~W}$, and $37^{\circ} \mathrm{C}$ 


\section{Effect of URS on biosynthesis of AA-2G}

Transglycosylation of $A A$ during production of AA-2G under UR with shaking at $150 \mathrm{rpm}$ (URS) was carried out with the same reaction mixture as described in the previous section. Maximum production of AA-2G $(2.78 \pm 0.10 \mathrm{~g} / \mathrm{L})$ was obtained at $500 \mathrm{~W}$ (Figure 2A). This yield represented a significant increase $(p<0.05)$ of $137.6 \%$ compared with that produced by the control $(1.17 \pm 0.07 \mathrm{~g} / \mathrm{L})$. The influences of reaction time at $\mathrm{pH} 8.0$ and $37{ }^{\circ} \mathrm{C}$ were also assessed, showing that the maximum production

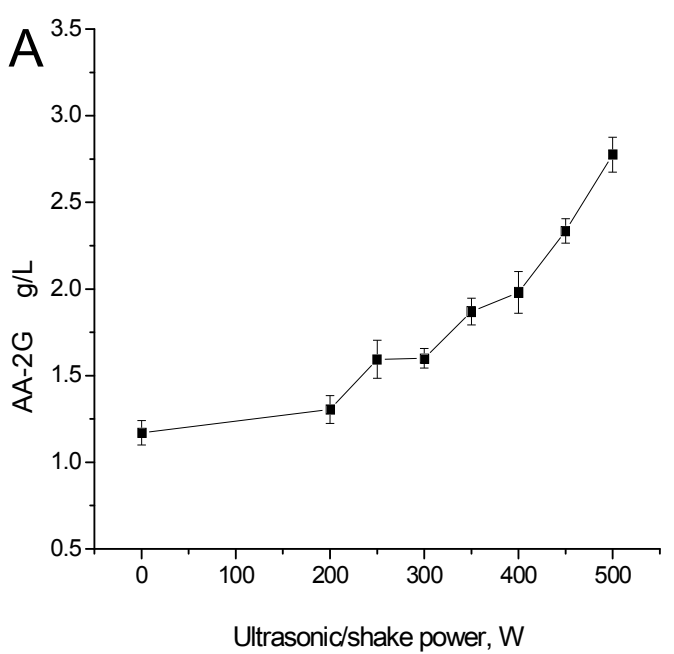

of $A A-2 G$ using URS for $14 \mathrm{~h}$ was $7.05 \pm 0.21 \mathrm{~g} / \mathrm{L}$ (Figure 2B).

Reaction parameters such as temperature, $\mathrm{pH}$, substrate ratios, and duration for AA-2G production using URS were optimized. URS induced a shift of the optimum temperature from 37 to $55^{\circ} \mathrm{C}$ for $2 \mathrm{~h}$, which was accompanied by a significant increase $(p<0.05)$ in AA-2G production from $2.78 \pm 0.10 \mathrm{~g} / \mathrm{L}$ to $3.31 \pm 0.08$ $\mathrm{g} / \mathrm{L}$ (Figure $3 \mathrm{~A}$ ). At $55^{\circ} \mathrm{C}, \mathrm{pH} 8.0$, and a $1: 1$ ratio (AA: maltodextrin), the reaction produced $A A-2 G$ yield of $6.6 \mathrm{~g} / \mathrm{L}$ in $6 \mathrm{~h}$.

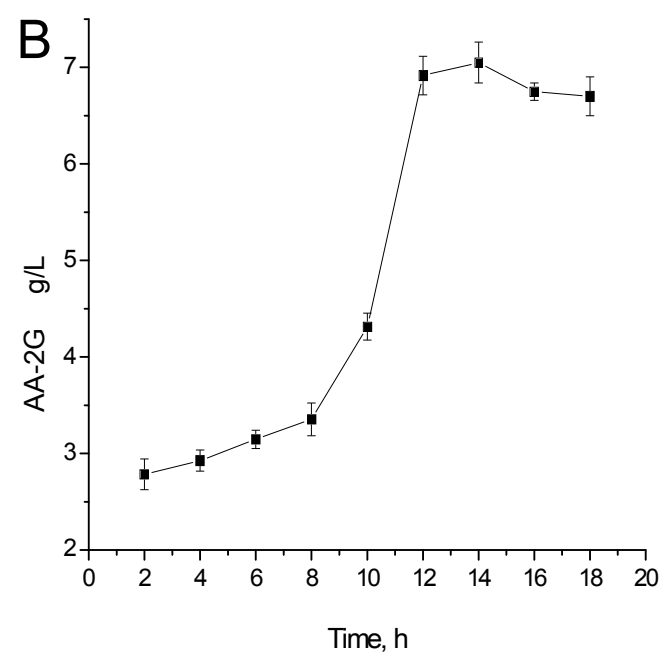

Figure 2: Effect of ultrasonic radiation with shake (URS) on $A A-2 G$ production at $37^{\circ} \mathrm{C}$ and $150 \mathrm{rpm}$. (A) The effects of different power for 2 hours and $(B)$ duration times at $500 \mathrm{~W}$

\section{Effect of URS on CGTase activity}

The influence of URS on hydrolytic and cyclization activities of CGTase from Bacillus sp. SK13.002 was determined by assaying the activities directly with URS (500 W/150 rpm). In addition, both activities were measured after USS (500 W/150 rpm) pretreatment at 37 and 55 ${ }^{\circ} \mathrm{C}$ for $2 \mathrm{~h}$. Table 1 shows a significant increase $(p<0.05)$ in hydrolytic and cyclization activities either directly measured with USS or after pretreatment for $2 \mathrm{~h}$, when compared to the activities of the control, directly measured with conventional SWB.

\section{DISCUSSION}

There have been recent improvements of $A A-2 G$ production by using maltodextrin as a highly soluble and low cost substrate $[3,10,11]$. Previously, we obtained a maximum yield of $A A$ $2 \mathrm{G}(6.3 \mathrm{~g} / \mathrm{L})$ using the following conditions: $24 \mathrm{~h}$ reaction time, $\mathrm{pH} 8,1: 1 \mathrm{AA}$ to maltodextrin ratio, and a temperature of $37{ }^{\circ} \mathrm{C}$ [7]. In the present study, we used UR and URS to assess the improvement of $\mathrm{AA}-2 \mathrm{G}$ production and to compare the present and previous results. The present results showed that both UR either without shaking or with shaking and short time treatment (2 hours) significantly increased AA-2G production by $82.05 \%$ and $137.6 \%$, respectively, compared to the control group. In addition, CGTase hydrolytic and cyclization activities, either measured directly under URS or after pretreatment by URS, were significantly increased. These results indicated that AA-2G production was improved due to activation of CGTase. Generally, UR in liquids induced heating and cavitation effects, and improved mass transfer [12]. As a result of this mass transfer, enzyme activity was enhanced due to the movement of reactants to the active site of the enzyme [13]. The hydrolysis rate for $2 \mathrm{~h}$ under shaking has been found to increase by 64 $\%$ as a result of UR compared to the control samples, which was attributed to less enzyme 

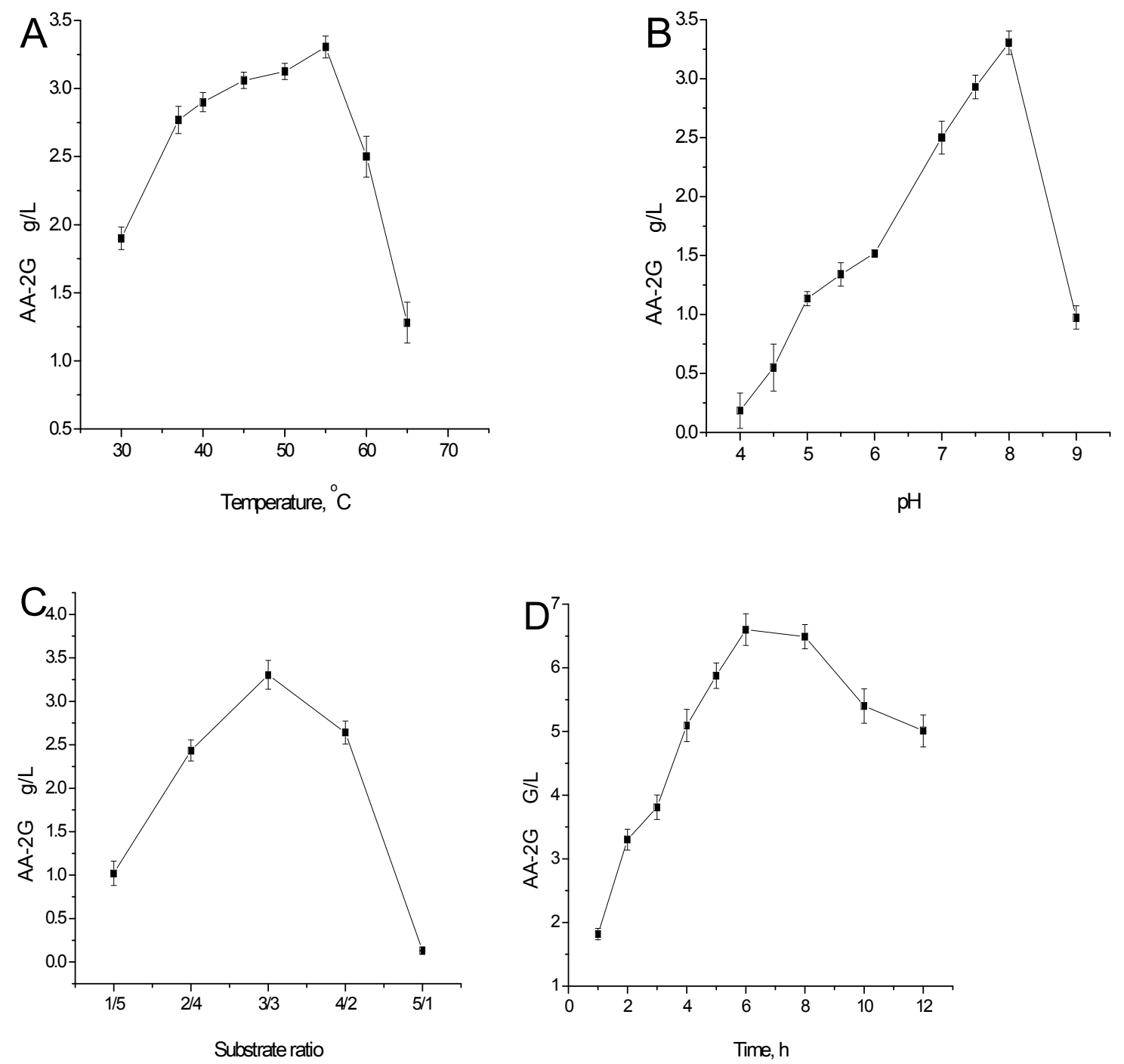

Figure 3: Effect with URS at $500 \mathrm{~W} / 150 \mathrm{rpm}$ of temperature $(\mathrm{A}), \mathrm{pH}(\mathrm{B})$, substrate ratio $(\mathrm{C})$, and duration of time (D)

Table 1: Effect of URS (500 W/150 rpm) treatment on hydrolysis and cyclization activities of CGTase

\begin{tabular}{llcc}
\hline Process conditions & Type of CGTase & $\begin{array}{c}\text { Hydrolytic activity } \\
(\mathbf{U} / \mathbf{m g})^{*}\end{array}$ & $\begin{array}{c}\text { Cyclization activity } \\
(\mathbf{U} / \mathbf{m g})^{*}\end{array}$ \\
\hline Direct & Control & $355.00 \pm 4.33^{\mathrm{a}}$ & $54.03 \pm 1.09^{\mathrm{a}}$ \\
Direct & URS & $366.67 \pm 1.11^{\mathrm{b}}$ & $55.73 \pm 0.70^{\mathrm{b}}$ \\
Pretreatment for 2 $\mathrm{h}$ & URS at $37^{\circ} \mathrm{C}$ & $363.05 \pm 3.19^{\mathrm{b}}$ & $57.56 \pm 0.71^{\mathrm{c}}$ \\
Pretreatment for $2 \mathrm{~h}$ & URS at $55^{\circ} \mathrm{C}$ & $369.29 \pm 4.62^{\mathrm{b}}$ & $61.56 \pm 0.43^{\mathrm{a}}$ \\
\hline
\end{tabular}

Results represent the mean \pm standard deviation $(S D, n=3)$; values with different superscript in the same column significantly are different $(p<0.05)$ using Duncan's least significant test

Treatment by UR produced an AA-2G yield of $5.69 \pm 0.2 \mathrm{~g} / \mathrm{L}$ which was less than that previously produced $(6.3 \mathrm{~g} / \mathrm{L})$ using SWB. However, URS either at $37{ }^{\circ} \mathrm{C}$ or $55{ }^{\circ} \mathrm{C}$ increased the AA-2G yield by $11.9 \%$ and $4.8 \%$, respectively, and reduced the process times by
$41.7 \%$ and $75 \%$, respectively, compared to our previous findings. These results indicated that shaking had a synergistic effect with UR, resulting in an improved $A A-2 G$ yield and reduced process time. This improvement could be due to acceleration of enzyme and substrate 
collisions, acceleration of substrate and product diffusion to and from the enzyme active site, and mild UR radiation-induced enzyme activation [15]. Previously, UR was found to increase reaction rates and yields of sugar ester biosynthesis, which were attributed to acceleration of the collision probability of enzyme and substrate [5].

\section{CONCLUSION}

The results of the present study demonstrated that UR could be used to carry out the transglycosylation reaction for production of $A A$ $2 \mathrm{G}$. Although the yield of $A A-2 G$ using UR was less than that by SWB, the yield and reaction time using URS significantly were improved compared to that to that previously produced using SWB. These finding indicated that shaking has synergistic effect with UR for improving AA$2 \mathrm{G}$ production.

\section{ACKNOWLEDGEMENT}

The research was supported by National Natural Science Foundation of China (nos. 31000764 and 31230057), International Cooperative Program of Jiangsu Province (noa. BZ2012031), and Science \& Technology Pillar Program of Jiangsu Province (nos. BE2012613, BY2012049, BE2013647, and BE2014703).

\section{REFERENCES}

1. Han R, Liu L, Li J, Du G, Chen J. Functions, applications and production of 2-O-D-glucopyranosyl-l-ascorbic acid. Appl Microbiol Biotechnol 2012; 95: 313-320.

2. Liu L, Han R, Shin HD, Li J, Du G, Chen J. Biosynthesis of 2-O-D-glucopyranosyl-L-ascorbic acid from maltose by an engineered cyclodextrin glycosyltransferase from Paenibacillus macerans. Carbohydr Res 2013; 382: 101-107.

3. Liu L, Xu Q, Han R, Shin HD, Chen RR, Li J, Du G, Chen J. Improving maltodextrin specificity for enzymatic synthesis of 2-O-D-glucopyranosyl-L-ascorbic acid by site-saturation engineering of subsite-3 in cyclodextrin glycosyltransferase from Paenibacillus macerans. J Biotechnol 2013; 166: 198-205.

4. Markosyan AA, Abelyan LA, Adamyan MO, Akopyan ZI, Abelyan VA. Transglycosylation of L-Ascorbic Acid. Appl Biochem Biotechnol 2007; 43: 36-40.
5. Xiao $Y M, W u Q$, Cai $Y$, Lin XF. Ultrasound-accelerated enzymatic synthesis of sugar esters in nonaqueous solvents. Carbohydr Res 2005; 340: 2097-2103.

6. Sun $T$, Jiang $B$, Pan $B$. Microwave accelerated transglycosylation of rutin by cyclodextrin glucanotransferase from Bacillus sp. SK13. 002. Int J Mol Sci 2011; 12: 3786-3796.

7. Eibaid $A$, Miao $M$, Bashari $M$, Musa $A$, Jiang $B$. Biosynthesis of 2- $\alpha$-D-glucopyranosyl-L-ascorbic acid from Maltodextrin Catalyzed by Cyclodextrin Glucanotransferase from Bacillus sp. SK13. 002. Journal of Academia and Industrial Research 2014; 2: $627-630$.

8. Kaneko $T$, Kato $T$, Nakamura $N$, Horikoshi $K$. Spectrophotometric determination of cyclization activity of $\beta$-cyclodextrin-forming cyclomaltodextrin glucanotransferase. J Jpn Soc Starch Sci 1987; 34: 45-48.

9. Park C, Park k, Kim S. A Rapid Screening Method for Alkaline $\beta$-Cyclodextrin Glucanotransferase using Phenolphthalein-Methyl Orange-containing-solid Medium. Agric Biol Chem 1989; 53:1167-1169.

10. Han $R$, Liu L, Shin HD, Chen RR, Du G, Chen J. Sitesaturation engineering of lysine 47 in cyclodextrin glycosyltransferase from Paenibacillus macerans to enhance substrate specificity towards maltodextrin for enzymatic synthesis of 2-O-D-glucopyranosyl-Lascorbic acid (AA-2G). Appl Microbiol Biotechnol 2013; 97: 5851-5860.

11. Han R, Liu L, Shin HD, Chen RR, Li J, Du G, Chen J. Systems Engineering of Tyrosine 195, Tyrosine 260, and Glutamine 265 in Cyclodextrin Glycosyltransferase from Paenibacillus macerans to Enhance Maltodextrin Specificity for 2-O-DGlucopyranosyl-L-ascorbic Acid Synthesis. Appl Environ Microbiol 2013; 79: 672-677.

12. Basto C, Silva CJ, Gübitz G, Cavaco-Paulo A. Stability and decolourization ability of Trametes villosa laccase in liquid ultrasonic fields. Ultrason Sonochem 2007; 14: 355-362.

13. Wang J, Cao $Y$, Sun B, Wang C, Mo $Y$. Effect of ultrasound on the activity of alliinase from fresh garlic. Ultrason Sonochem 2011; 18: 534-540.

14. Liu $Y$, Jin $Q$, Shan $L$, Liu $Y$, Shen $W$, Wang $X$. The effect of ultrasound on lipase-catalyzed hydrolysis of soy oil in solvent-free system. Ultrason Sonochem 2008; 15 : 402-407.

15. Zhang DN, Guo XY, Yang QH, Chen ZG, Tao LJ. An efficient enzymatic modification of cordycepin in ionic liquids under ultrasonic irradiation. Ultrason Sonochem 2014; 21: 1682-1687. 